\title{
AKTSENDIKORPUS JA VÕõRKEELE AKTSENDI UURIMINE
}

\author{
LYA MEISTER, EINAR MEISTER
}

\section{Sissejuhatus}

$\mathrm{E}$ esti keele kui võõrkeele õpetamise ja õppimisega seotud probleemide uurimine ning vastava keeleainestiku kogumine on viimasel kümnendil hoogustunud. Tallinna Tehnikaülikooli Küberneetika Instituudis loodav aktsendikorpus ${ }^{1}$ sisaldab eesti keelt võõrkeelena kõnelevate inimeste hääldusnäiteid aktsendi akustilis-foneetiliseks uurimiseks.

Aktsendi tekkepõhjused ja olemus on keeleteadlastele ja psühholoogidele huvi pakkunud pikka aega. Põhimõtteliselt on iga inimene võimeline peale emakeele omandama mis tahes võorrkeele, selleks on tal olemas kõik anatoomilised ja kognitiivsed eeldused. Kuid kui võõrkeele õppimisega alustatakse teismeeas või alles täiskasvanuna, on tavaliselt paratamatu kaasnähtus sihtkeele tüüpilisest hääldusest hälbiv kõne, mida selle keele sünnipärased kõnelejad tajuvad võõrkeelse aktsendina. Kuid aktsent pole ainult keeleteaduslik uurimisobjekt - aktsendiprobleem on tõusnud päevakorda ka seoses keeletehnoloogia arengu ja rakendustega. Juba aastaid on saadaval kõnetuvastussüsteemid, mis võimaldavad sisestada arvutisse teksti dikteerides. Neid on loodud piiratud arvu keelte, eelkõige suure kõnelejatearvuga keelte (inglise, prantsuse, saksa, hispaania jt) jaoks, ja need tuvastavad emakeelsete kasutajate kõnet peaaegu sajaprotsendiliselt. Paraku pole näiteks ingliskeelsest kõnetuvastusest kuigi palju abi eesti emakeelega arvutikasutajale, kes püüab dikteerida arvutile ingliskeelset teksti - paremal juhul tuvastatakse korrektselt vaid üksikud sõnad. Põhjus on selles, et tuvastusprogramm on treenitud emakeelsete kõnenäidete abil ja aktsendiga kõnet ei ole see võimeline tuvastama.

Käesolevas artiklis anname ülevaate aktsendi olemusest ja teoreetilistest käsitlustest, tutvustame aktsendikorpuse eesmärke, ülesehitust ja salvestusi, esitame näiteid aktsendiuuringute tulemustest.

\section{Aktsendi olemusest}

Kuigi aktsent on lihtsalt tajutav ja intuitiivselt arusaadav mõiste, ei ole sellel korrektset definitsiooni. Üldise konsensuse kohaselt mõistetakse termini võorrkeele aktsent all kõrvalekallet keelele omasest tüüpilisest hääldusest, mis on tingitud kõneleja emakeelest. Murray Munro (2006) loetleb võõrkeelse aktsendiga kõne tunnustena järgmisi tegureid: 1) kõneleja ei räägi oma emakee-

1 Aktsendikorpuse loomist on toetanud riiklikud programmid „Eesti keele keeletehnoloogiline tugi (2006-2010)” ja „Eesti keeletehnoloogia (2011-2017)”. 
les, 2) erineb süstemaatiliselt emakeelsest kõnest, 3) ei ole patoloogiline, 4) hälbed on kuuldeliselt tajutavad.

Üldtunnustatud seisukoha järgi on võõrkeelse aktsendi peamiseks põhjuseks imikueas omandatud emakeelsed hääldus- ja tajumallid (Polivanov 1931; Trubetzkoy 1939; Lado 1957; Lenneberg 1967; Selinker 1972; Kuhl 1991; Best 1994; Flege 1995; Major 2001 jt). Keelemallide omandamise eelduseks on kategoriaalne taju - see on kõnetaju võime jagada pidevalt muutuvat kõnesignaali diskreetseteks üksusteks ja klassifitseerida neid üksusi erinevateks foneetilisteks/fonoloogilisteks kategooriateks. Imikute keelelist arengut uurides on leitud, et kategoriaalne taju on sünnipärane võime (Eimas jt 1987). Esimese eluaasta jooksul omandab laps oma emakeele põhilised fonoloogilised kategooriad (nt Cheour jt 1998) ja õpib segmenteerima pidevat kõnesignaali erinevateks segmentideks - vokaalideks ning konsonantideks. Vokaalikategooriad kujunevad imikul välja esimese kuue elukuu jooksul (Kuhl jt 1992; Polka, Werker 1994), konsonantide kategooriad aga 10-12 kuu vanuselt (Werker, Tees 1984). Emakeele häälikumallide omandamise järel tekib nn fonoloogiline kurtus, s.t lapse kõnetaju kurdistub emakeeles mitteesinevate kategooriate suhtes ja põhjustab raskusi võõrkeeles esinevate fonoloogiliste kontrastide tajumisel ning võõrkeele häälduse omandamisel (Dupoux, Peperkamp 2002).

Eric Lennebergi (1967) kriitilise perioodi hüpoteesi kohaselt on keele omandamise võime seotud bioloogilise vanusega ja võõrkeelt on võimalik omandada aktsendivabalt kuni puberteedieani (10-16 a), mil aju on veel piisavalt plastiline ja võimeline kohanema õpitava keele struktuuridega. Hilisemas eas kaotab aju sellise kohanemisvõime ja keelestruktuuride täiuslik omandamine pole enam võimalik. Lennebergi väite kohaselt kehtib see kognitiivne piirang nii L1 kui ka L2 omandamise kohta ${ }^{2}$ ja seda on kinnitanud mitmed hilisemad uuringud (Johnson, Newport 1989; Birdsong, Molis 2001 jt). Michael Longi (1990) tundliku perioodi hü potees väidab, et keele omandamise võime ei kao tundliku perioodi lõppedes järsult, vaid see väheneb järk-järgult. Mitmed hilisemad uuringud on näidanud, et võõrkeelse häälduse omandamine emakeelsete kõnelejatega lähedasel tasemel on siiski võimalik ka täiskasvanud keeleõppijate korral (Birdsong 2007; Bongaerts jt 1995; Young-Scholten 2002; vt ülevaadet Birdsong 2006).

Fonoloogiline kurtus L2 kategooriate suhtes on määratud eelkõige L1 fonoloogilise süsteemiga, see ilmneb erinevate võõrkeelte puhul erinevalt (sõltuvalt võõrkeele fonoloogilisest süsteemist) ja võib esineda nii segmentaalsete kui ka prosoodiliste kategooriate tajumisel. Toome siinkohal mõned näited: 1) jaapanlastel on raskusi eristada inglise keele foneeme /r/ ja /1/ (nt Yamada 1995), sest jaapani keeles on ainult üks liikvida - /r/, mis kuuldeliselt on lähedasem pigem inglise ///le kui /r/-le (Takagi 1993); 2) hispaania emakeelega kõnelejad ei erista inglise vokaalfoneeme /i/ ja /I/ ning vastendavad neile hispaania keele /i/-vokaali (Flege 1991); 3) kontrastiivne kestus (lühikeste-pikkade foneemide vastandus) on omane kvantiteedikeeltele, näiteks jaapani, eesti ja soome keelele, kuid kestusvastandust ei esine näiteks prantsuse, vene ja hispaania keeles; 4) rõhu akustilisteks korrelaatideks on valjus, põhitooni sagedus ja kestus (Lehiste 1970), kuid mitte kõik keeled ei kasuta neid

2 Kasutame artiklis emakeele ja võõrkeele (teise keele) tähistena rahvusvaheliselt tuntud lühendeid L1 ja L2. 
tunnuseid rõhu väljendamiseks - kontrastiivse kestusega keeltes ei ole kestus rõhu peamiseks korrelaadiks (Hayes 1995), näiteks eesti keeles on rõhk seotud valjuse ja põhitooniga (Eek 1987), kuid vene keeles eelkõige kestusega (Bondarko 1977).

Täiskasvanud keeleõppija erinevaid fonoloogilise kurtuse põhjusi ja L2 omandamise eri aspekte käsitlevad kaks üldtuntud aktsendimudelit: pertseptiivse assimilatsiooni mudel (Best, Tyler 2007) ja kõne õ p imise mudel (Flege 1995). Mõlema mudeli kohaselt sõltub L2 häälikusüsteemi omandamise edukus L1 ja L2 kategooriate foneetilise kauguse tajust: 1) akustiliselt ja pertseptiivselt lähedasi L2 kategooriaid on raske eristada ja need assimileeruvad vastava(te) L1 kategooria(te)ga; 2) L1 ja L2 kategooriate assimilatsioon toimub allofoonilisel, mitte abstraktsete foneemide tasandil; 3) L1-st akustiliselt ja pertseptiivselt erineva L2 häälikuklassi jaoks luuakse uus kategooria.

1960.-1970. aastatel rakendati võõrkeele õpetamise ja õppimisega seotud probleemide uurimisel kontrastiivanalü üsi (Lado 1957) meetodit. Selle kohaselt on aktsendinähtuste selgitamise aluseks L1 ja L2 fonoloogiliste süsteemide kontrastiivne võrdlus ja aktsendi põhilise põhjusena nähakse L1 fonoloogilise süsteemi elementide negatiivset ülekannet (interferentsi) L2 hääldusesse. Hilisemad uuringud on näidanud, et L2 kategooriate taju ei saa alati seletada L1 kategooriate ülekandega. Näiteks inglise keele vokaalid /i/ ja /I/ erinevad teineteisest nii spektraalselt kui ka kestuselt. Inglise emakeelega kuulajad eristavad neid vokaale eelkõige spektraalsete tunnuste alusel, kuid hispaania ja hiina emakeelega kuulajad kestuse alusel, s.t nad kasutavad akustilist tunnust, mida nende emakeele fonoloogiline süsteem ei kasuta kontrastiivselt. Eksperimendid näitasid, et L2 vokaalide kuuldelisel eristamisel on kestus hõlpsasti tajutav tunnus sõltumata sellest, kas kuulajate L1 kasutab kestust kontrastiivselt või mitte. Nende tulemuste alusel on sõnastatud desensibiliseerimise hüpotees (Bohn 1995), mis väidab, et kui spektraalsed tunnused ei ole L2 kuulaja jaoks vokaalikontrastide eristamiseks piisavad (s.t L1 kategooriad on muutnud L2 taju tundetuks spektraalsete tunnuste suhtes - sellest tuleneb ka hüpoteesi nimetus), siis eristatakse vokaale nende kestuse alusel. Et see hüpotees kehtib L2 kuulajate puhul, kelle emakeeles ei esine kestusvastandust, siis ei saa olla tegemist L1 tajumehhanismi ülekandega, vaid tõenäoliselt on tegemist üldise kõnetajule omase mehhanismiga.

Eelnevale hüpoteesile vaidleb osaliselt vastu tunnuse hüpotees, mis väidab, et „L2 kuulajal on raske tajuda L2 tunnust, mida tema emakeel ei kasuta fonoloogiliste kontrastide loomisel, ja seetõttu on keeleõppijal raskusi sellel tunnusel põhinevate kontrastide realiseerimisega L2 häälduses" (McAllister jt 2002). Tunnuse hüpoteesile annavad empiirilist tuge kestuskategooriate tajukatsetes saadud tulemused. Nii on uuritud rootsi keele kategooriate lühike/pikk eristamist hispaania, inglise ja eesti emakeelega kuulajate poolt. Neis keeltes on kestusel erinev roll: hispaania keel ei kasuta kestust kontrastiivselt, inglise vokaalide tense/lax vastandus põhineb spektritunnuste ja kestuse koostoimel, eesti keeles on kestus fonoloogiline ja vastandus lühike/pikk esineb kõigi vokaalide ning konsonantide puhul. Hüpoteesi kohaselt võib oodata, et inglise ja hispaania emakeelega kuulajatel on raskusi rootsi kvantiteedivastanduste tajumisel ja hääldamisel, eesti kuulajatel aga mitte. Katsetulemu- 
sed kinnitasid hüpoteesi: eesti kuulajate taju ja hääldus olid lähedased rootsi emakeelega katsealustele, hispaania rühma tulemused olid kõige halvemad, inglise rühma tulemused olid aga hispaania ja eesti rühma vahepealsed. Tulemused näitasid, et kestusel põhinevate L2 kategooriate omandamise edukus sõltub kestuse rollist L1-s (McAllister jt 2002). Siiski ei lükka need tulemused veel ümber desensibiliseerimise hüpoteesi, sest kirjeldatud eksperimendid käsitlesid erinevate fonoloogiliste kategooriate taju.

Aktsendi teket põhjendatakse sageli ka sellega, et eri keeltele on omane erinev kõneorganite kasutus, s.t keeled erinevad huulte ümardatuse, huulte ja keele pingsuse, foneerimise viisi, alalõua asendi, põhitooni registri ja ulatuse jms poolest. Kõneaparaadi keelespetsiifilist lähteasendit tähistatakse terminitega hääldusalus, artikulatsioonibaas, keele alus, foneetiline seadistus, artikulatoorne seadistus, artikulatoorne alus (Mennen jt 2010; vt ajalooline ülevaade Jenner 2001); vene keeleteaduses on kasutatud valdavalt terminit артикуляиионная база (nt Kolosov 1971; Kuznetsova 1975; Kulešov, Mišin 1987; Ljubimova 1985). Toetust keelespetsiifilise hääldusaluse olemasolule on andnud artikulatsiooniorganite staatilised röntgenülesvõtted (Gick jt 2004) ja ka artikulatsiooni ultraheliuuringud (Wilson, Gick 2006a, 2006b). Samal ajal pole piisavat empiirilist tõestust sellele, et kõneorganite liikumatus asendis leitud erinevused tõepoolest mõjutavad häälikute dünaamilisi artikulatsioonimustreid ja et just hääldusalus on võõrkeelse aktsendi põhjuseks. Seetõttu on tegemist siiski pigem hüpoteesiga (Mennen jt 2010).

Eelnevast ülevaatest näeme, et võõrkeele aktsent on oma olemuselt vägagi keerukas nähtus ja erinevaid aktsendiilminguid võib interpreteerida erinevate teoreetiliste mudelite kontekstis.

\section{Aktsendikorpusi maailmas}

Erinevate keelenähtuste uurimiseks kogutakse ja kasutatakse tänapäeval suuri elektrooniliselt töödeldavaid korpusi. Valdav osa maailmas kogutud kõnekorpustest sisaldavad keelejuhtide emakeelseid kõnesalvestusi, aktsendiga kõne korpusi on suhteliselt vähe ja suur osa neist on sellised, kus L2 on inglise keel (vt nt ülevaade Raab jt 2007). Näiteks TED - Translanguage English Database (Lamel jt 1994) - sisaldab rahvusvahelise konverentsi (Eurospeech' 93) 188 ettekande ingliskeelseid salvestusi, kõigi keelejuhtide jaoks on inglise keel võõrkeeleks; CSLU: Foreign Accented English (Lander 2007) hõlmab 22 eri keeletaustaga keelejuhi L2 kõnenäiteid; The Wildcat Corpus of Native- and Foreign-accented English (Van Engen jt 2010) sisaldab 24 ameerika inglise keele kõneleja ja 52 muu emakeelega keelejuhi kõnesalvestusi. Korpusi, mille puhul sihtkeeleks on mingi muu keel, on suhteliselt vähe, mõned näited: The LeaP corpus (Milde, Gut 2002) sisaldab saksa ja inglise keelt võõrkeelena kõnelevate keelejuhtide salvestusi (kokku 131 keelejuhti 32 eri emakeele taustaga); JASMIN-CGN Corpus (Cucchiarini jt 2008) on hollandi keele korpus, mis muuhulgas sisaldab ka L2 alamkorpust; SINOD (Žgank jt 2006) - L2 sloveenia keele korpus sisaldab kahe keelejuhi intervjuusid; EURONOUNCE corpus - L2 poolakeelse kõne korpus (Cylwik jt 2009) jm.

Eri korpuste loomisel on peetud silmas erinevaid korpuse kasutamise eesmärke: 
- automaatne kõnetuvastus (TED, CSLU ja SINOD);

- L2 suhtluse uurimine (Wildcat);

- L2 prosoodia uurimine (LeaP);

- inimene-masin dialoogi uurimine (JASMIN);

- L2 hääldustreeningu programmi arendamine (EURONOUNCE).

\section{Aktsendikorpuse loomine}

Eesti aktsendikorpuse kavandamisel ei ole me võtnud otseseks eeskujuks ühtegi konkreetset L2 kõnekorpust ega kasutuseesmärki. Lähtusime varasematest kogemustest erinevate L1 korpuste, eeskätt BABEL-i korpuse (Eek, Meister 1999) loomisel ja kõnematerjali kogumise praktikast, samuti kõnekorpuste kavandamise üldisest metoodikast (Schiel, Draxler 2003). Korpuse esmane eesmärk on pakkuda süstemaatilist ja kvaliteetset uurimismaterjali eesti keele kui võõrkeele häälduse eksperimentaalfoneetiliseks uurimiseks, kuid silmas on peetud ka võimalikke keeletehnoloogilisi rakendusi, nagu näiteks kõnetuvastuse treenimine aktsendiga kõne tuvastamiseks, kõneleja emakeele automaatne tuvastamine, eesti keele hääldustreeningu programmi loomine jm.

Tekstikorpus. Kõnenäidete salvestamisel kasutatav tekstikorpus sisaldab neutraalseid lauseid (130), milles on esindatud kõik eesti vokaalid ja konsonandid kolmes erivältelises sõnastruktuuris (kahesilbilistes sõnades), sagedasemad diftongid ja konsonantühendid, küsilaused (8) ja kaks pikemat tekstilõiku (5-6 lauset). Arvestades keelejuhtide erinevat keeleoskust, on konstrueeritud laused valdavalt lihtlaused, nii et kesktasemel keeleoskusega inimene mõistaks nende sisu ja saaks lugemisega kergesti hakkama. Lisaks tekstide ettelugemisele soovime saada keelejuhtidelt ka spontaanse kõne näiteid. Selleks palume keelejuhtidel kirjeldada kolme pilti ning esitame suunavaid küsimusi, mille põhjal keelejuht räägib oma päritolust ja perekonnast, kus ja kui kaua on ta õppinud eesti keelt, kui sageli ja mis olukordades ta eesti keelt kasutab, millised probleemid on tekkinud eesti keeles suheldes jm. Järgnevalt mõned näited.

(a) Vokaalikeskse vältevastandusega sõnad

Kaotasin sada krooni raha.

Sügisel pandi vili salvedesse.

Palun saada talle artikli koopia.

Soovin saada kolme kuu aruannet.

Selle viili käepide oli murdunud.

Uut viili kasutage ettevaatlikult.

(b) Konsonandikeskse vältevastandusega sõnad

Kaunis lugu kõlas raadiost.

Uue luku paigaldus maksab sada krooni.

Vana lukku pole mõtet parandada.

(c) Diftonge sisaldavad sõnad

Mees ajas kiusu ainult kiusu pärast.

See köide viidi Pöide juba eile.
Õhtul kasi koju magama.

Musta kassi sabaots oli valge. Musta kassi nähes lõi ta araks. 
Selle tuima laulu lõid uue laine muusikud.

Kahte tuima laulu ei jaksa keegi kuulata.

(d) Konsonantühendeid sisaldavad sõnad

Looma kõrva taha tehti süst.

Haiget kõrva soojendage viis päeva.

Pole lootustki, et ta selle palve täidab.

Rumba ja samba kuuluvad minu lemmiktantsude hulka.

(e) Küsilaused

Kes tuleb minuga uisutama?

Mida te seal omavahel sosistate?

Kas sa tead Peetri uut telefoninumbrit?

Mis kell väljub lennuk Pariisi?

Kuidas on selle pikkade juustega tüdruku nimi?

(f) Tekstilõik

Kui Arno isaga koolimajja jõudis, olid tunnid juba alanud. Kooliõpetaja kutsus mõlemad oma tuppa, kõneles nendega natuke aega, käskis Arnol olla hoolas ja korralik ja seadis ta siis pinki ühe pikkade juustega poisi kõrvale istuma. Siis andis kooliõpetaja talle raamatust midagi kirjutada, ja Arnol ei olnud nü̈̈d enam aega muule mõelda. Ta võttis tahvli ja hakkas kirjutama.

Keelejuhtide valikukriteeriumid ja värbamine. Keelejuhtide valikul on peamisteks kriteeriumideks keelejuhi eesti keele oskus ja tema emakeel. Kindlasti on oluline, et keelejuhi kõnes on võõraktsent kuuldeliselt tajutav, oleme püüdnud vältida kakskeelseid keelejuhte, kelle eestikeelne kõne on peaaegu samal tasemel kui eesti emakeelega kõnelejatel. Salvestatud on ainult täiskasvanud keelejuhte, nii mehi kui ka naisi, kelle puhul keeleõppe seisukohalt kriitiline periood on ületatud, s.t alates vanusest 16-17 eluaastat. Ideaalne oleks sama emakeelega mees- ja naiskeelejuhtide võrdne esindatus korpuses, kuid selle saavutamine on väga raske ja seda pole püütudki teha. Veel on jälgitud, et keelejuhil ei esine kõne- ja kuulmisprobleeme.

Sobivate keelejuhtide leidmiseks Eestis on kasutatud mitmeid meetodeid - üleskutseid salvestusel osaleda on levitatud ülikoolides, kolleegide ja sõprade kaudu, aga ka ajakirjanduses. Vene emakeelega keelejuhtide leidmine Tallinnas pole olnud keeruline, küll aga on suhteliselt raskem olnud muu keeletaustaga kõnelejate värbamine. Mitmed salvestused on tehtud välismaa ülikoolis, kus õpetatakse eesti keelt, näiteks Soomes Helsingi, Turu ja Oulu ülikoolides, Prantsusmaal INALCO-s, Austrias Viini ülikoolis ja viimati Läti Ülikoolis Riias.

Lisaks L2 keelejuhtidele on salvestatud ka 20 eesti emakeelega keelejuhi (10 meest, 10 naist) kõnenäited. See nn kontrollgrupp on vajalik võrdlusbaasiks, mille suhtes hinnata L2 kõnest akustilis-foneetilisel analüüsil leitud tunnuste variatsioone. 
Keelejuhi ankeet. Kõik keelejuhid täitsid ankeedi, mis lisaks isiklikele andmetele (nimi, sugu, rahvus, vanus, elukohariik ja -linn) sisaldas küsimusi nende keeletausta (emakeel, kodune keel, võõrkeelte valdamine) ja eesti keele õppimise ning kasutamise kohta:

- Kui vanalt hakkasid õppima eesti keelt?

- Kuidas õppisid eesti keelt? (Vastusevariandid: a) iseseisvalt, b) koolis/ ülikoolis, c) keelekursustel, d) sõpradega suheldes, e) eraõpetajaga).

- Kui sageli kasutad eesti keelt? (Vastusevariandid: a) iga päev, b) nädalas mitu korda, c) nädalas korra, d) mõned korrad kuus, e) mõned korrad aastas).

- Kuidas hindad oma eesti keele taset? (Vastusevariandid: a) algtase, b) keskmine, c) hea, d) väga hea).

Isikuandmete kaitsest tulenevalt on keelejuhtide nimed korpuses asendatud tähekoodidega. Ankeeti allkirjastades annab keelejuht nõusoleku tema kõnesalvestuste kasutamiseks uurimistöö eesmärkidel.

Salvestuse tehnilised tingimused. Suurem osa keelejuhtidest on salvestatud TTÜ Küberneetika Instituudi foneetika ja kõnetehnoloogia labori stuudios, kus on tagatud salvestuste kõrge kvaliteet. Stuudiosalvestused on tehtud kahe mikrofoniga, millest üks on statiivimikrofon (Audio-Technica ATM33a) ja paikneb keelejuhi huultest umbes $20 \mathrm{~cm}$ kaugusel, teine aga peamikrofon (Sennheiser ME3), kaugus huultest 2-3 cm. Salvestusteks kasutatakse arvutiprogrammi Adobe Audition, signaalid salvestatakse digitaalselt (võendamissagedus $44,1 \mathrm{kHz}$, resolutsioon 16 bitti, stereo, wav-formaat) arvuti kõvakettale.

Salvestussessiooni ajal kuvatakse tekstikorpuse laused arvutiekraanile ühekaupa. Salvestust juhib foonikaruumis operaator, kes jälgib ka lausete lugemise korrektsust: kui keelejuht teeb lause lugemisel vea, siis juhib operaator sellele keelejuhi tähelepanu ja annab vajadusel selgitusi, milles viga seisneb. Seejärel loeb keelejuht lause uuesti. Salvestus tehakse ühe sessioonina, mis sõltuvalt keelejuhist kestab keskmiselt 25-30 minutit; salvestuse kestel lubatakse keelejuhile kaks lühikest puhkepausi.

Keelejuhtide statistika. Järgnev tabel annab ülevaate aktsendikorpuses esindatud L2 keelejuhtide andmetest.

Tabel 1 .

\begin{tabular}{|c|c|c|c|c|c|c|c|}
\hline Emakeel & $\begin{array}{l}\text { Keele- } \\
\text { juhtide arv } \\
\text { (mehi, } \\
\text { naisi) }\end{array}$ & $\begin{array}{l}\text { Vanuse- } \\
\text { piirid }\end{array}$ & $\begin{array}{l}\text { Kui vanalt } \\
\text { hakati } \\
\text { öppima } \\
\text { eesti keelt }\end{array}$ & $\begin{array}{l}\text { Kuidas } \\
\text { oppiti eesti } \\
\text { keelt }\end{array}$ & $\begin{array}{l}\text { Kui sageli } \\
\text { kasutatakse } \\
\text { eesti keelt }\end{array}$ & $\begin{array}{l}\text { Kuidas } \\
\text { hinnatakse } \\
\text { oma eesti } \\
\text { keele } \\
\text { oskust } \\
\end{array}$ & $\begin{array}{l}\text { Muud } \\
\text { võõrkeeled }\end{array}$ \\
\hline vene & $53(17,36)$ & $19-55$ & $0-20$ & $\begin{array}{ll}\text { a) } & 20 \\
\text { b) } & 50 \\
\text { c) } & 11 \\
\text { d) } & 31 \\
\text { e) } & 5\end{array}$ & $\begin{array}{l}\text { a) } 34 \\
\text { b) } 12 \\
\text { c) } 5 \\
\text { d) } 2 \\
\text { e) } 0\end{array}$ & $\begin{array}{ll}\text { a) } & 2 \\
\text { b) } 19 \\
\text { c) } 22 \\
\text { d) } 10\end{array}$ & $\begin{array}{l}\text { inglise } \\
\text { saksa } \\
\text { soome } \\
\text { prantsuse } \\
\text { taani }\end{array}$ \\
\hline soome & $30(10,20)$ & $19-62$ & $18-47$ & $\begin{array}{ll}\text { a) } & 8 \\
\text { b) } & 23 \\
\text { c) } & 10 \\
\text { d) } & 5 \\
\text { e) } & 0 \\
\end{array}$ & $\begin{array}{l}\text { a) } 4 \\
\text { b) } 6 \\
\text { c) } 3 \\
\text { d) } 6 \\
\text { e) } 11\end{array}$ & $\begin{array}{l}\text { a) } 10 \\
\text { b) } 15 \\
\text { c) } 3 \\
\text { d) } 2\end{array}$ & $\begin{array}{l}\text { inglise } \\
\text { rootsi } \\
\text { saksa } \\
\text { prantsuse } \\
\text { vene }\end{array}$ \\
\hline läti & $19(1,18)$ & 19-39 & $7-23$ & $\begin{array}{ll}\text { a) } & 6 \\
\text { b) } & 18 \\
\text { c) } & 3 \\
\text { d) } & 5 \\
\text { e) } & 2 \\
\end{array}$ & $\begin{array}{l}\text { a) } 2 \\
\text { b) } 14 \\
\text { c) } 0 \\
\text { d) } 2 \\
\text { e) } 0\end{array}$ & $\begin{array}{ll}\text { a) } & 3 \\
\text { b) } & 11 \\
\text { c) } & 3 \\
\text { d) } & 1\end{array}$ & $\begin{array}{l}\text { inglise } \\
\text { soome } \\
\text { vene } \\
\text { saksa } \\
\text { rootsi } \\
\end{array}$ \\
\hline
\end{tabular}




\begin{tabular}{|c|c|c|c|c|c|c|c|}
\hline saksa & $15(11,4)$ & $16-53$ & $16-43$ & $\begin{array}{ll}\text { a) } & 8 \\
\text { b) } & 8 \\
\text { c) } & 3 \\
\text { d) } & 7 \\
\text { e) } & 2 \\
\end{array}$ & $\begin{array}{l}\text { a) } 8 \\
\text { b) } 2 \\
\text { c) } 1 \\
\text { d) } 2 \\
\text { e) } 2\end{array}$ & $\begin{array}{l}\text { a) } 3 \\
\text { b) } 8 \\
\text { c) } 3 \\
\text { d) } 1\end{array}$ & $\begin{array}{l}\text { inglise } \\
\text { prantsuse } \\
\text { vene } \\
\text { norra } \\
\text { hispaania }\end{array}$ \\
\hline prantsuse & $13(8,5)$ & $23-67$ & $20-36$ & $\begin{array}{ll}\text { a) } & 4 \\
\text { b) } & 1 \\
\text { c) } & 3 \\
\text { d) } & 9 \\
\text { e) } & 1 \\
\end{array}$ & $\begin{array}{l}\text { a) } 5 \\
\text { b) } 7 \\
\text { c) } 0 \\
\text { d) } 1 \\
\text { e) } 0\end{array}$ & $\begin{array}{l}\text { a) } 2 \\
\text { b) } 3 \\
\text { c) } 4 \\
\text { d) } 4\end{array}$ & $\begin{array}{l}\text { inglise } \\
\text { saksa } \\
\text { soome } \\
\text { itaalia } \\
\text { hispaania }\end{array}$ \\
\hline inglise & $5(5,0)$ & $17-45$ & $16-30$ & $\begin{array}{ll}\text { a) } & 3 \\
\text { b) } & 1 \\
\text { c) } & 3 \\
\text { d) } & 2 \\
\text { e) } & 2\end{array}$ & $\begin{array}{ll}\text { a) } & 4 \\
\text { a) } & 1 \\
\text { b) } & 0 \\
\text { c) } & 0 \\
\text { d) } & 0\end{array}$ & $\begin{array}{ll}\text { a) } & 2 \\
\text { b) } & 1 \\
\text { c) } & 1 \\
\text { d) } & 1\end{array}$ & $\begin{array}{l}\text { saksa } \\
\text { soome } \\
\text { prantsuse }\end{array}$ \\
\hline hispaania & $5(2,3)$ & $19-41$ & $18-30$ & $\begin{array}{ll}\text { a) } & 3 \\
\text { b) } & 3 \\
\text { c) } & 3 \\
\text { d) } & 3 \\
\text { e) } & 1 \\
\end{array}$ & $\begin{array}{ll}\text { a) } & 3 \\
\text { b) } & 1 \\
\text { c) } & 1 \\
\text { d) } & 0 \\
\text { e) } & 0 \\
\end{array}$ & $\begin{array}{ll}\text { a) } & 3 \\
\text { b) } & 1 \\
\text { c) } & 0 \\
\text { d) } & 1\end{array}$ & $\begin{array}{l}\text { inglise } \\
\text { saksa } \\
\text { prantsuse } \\
\text { vene }\end{array}$ \\
\hline itaalia & $5(5,0)$ & $21-45$ & $16-30$ & $\begin{array}{ll}\text { a) } & 2 \\
\text { b) } & 2 \\
\text { c) } & 2 \\
\text { d) } & 3 \\
\text { e) } & 1 \\
\end{array}$ & $\begin{array}{l}\text { a) } 4 \\
\text { b) } 1 \\
\text { c) } 1 \\
\text { d) } 0 \\
\text { e) } 0\end{array}$ & $\begin{array}{ll}\text { a) } & 3 \\
\text { b) } & 2 \\
\text { c) } & 0 \\
\text { d) } & 0\end{array}$ & $\begin{array}{l}\text { inglise } \\
\text { hispaania } \\
\text { soome } \\
\text { araabia }\end{array}$ \\
\hline leedu & $3(0,3)$ & $51-57$ & $24-30$ & $\begin{array}{ll}\text { a) } & 1 \\
\text { b) } & 0 \\
\text { c) } & 2 \\
\text { d) } & 2 \\
\text { e) } & 0\end{array}$ & a) 3 & $\begin{array}{ll}\text { a) } & 0 \\
\text { b) } & 1 \\
\text { c) } & 1 \\
\text { d) } & 1\end{array}$ & $\begin{array}{l}\text { vene } \\
\text { inglise }\end{array}$ \\
\hline hindi & $3(3,0)$ & $36-48$ & $25-32$ & $\begin{array}{ll}\text { a) } & 2 \\
\text { b) } & 1 \\
\text { c) } & 1 \\
\text { d) } & 3 \\
\text { e) } & 0 \\
\end{array}$ & a) 3 & $\begin{array}{ll}\text { a) } & 1 \\
\text { b) } & 0 \\
\text { c) } & 2 \\
\text { d) } & 0\end{array}$ & $\begin{array}{l}\text { marathi } \\
\text { prantsuse } \\
\text { punjabi } \\
\text { inglise } \\
\text { vene }\end{array}$ \\
\hline hollandi & $2(2,0)$ & $36-38$ & $33-34$ & $\begin{array}{ll}\text { a) } & 2 \\
\text { b) } & 0 \\
\text { c) } & 2 \\
\text { d) } & 1 \\
\text { e) } & 0\end{array}$ & a) 2 & $\begin{array}{ll}\text { a) } & 1 \\
\text { b) } & 0 \\
\text { c) } & 1 \\
\text { d) } & 0\end{array}$ & $\begin{array}{l}\text { inglise } \\
\text { saksa } \\
\text { prantsuse }\end{array}$ \\
\hline taani & $2(1,1)$ & $31-35$ & $23-29$ & $\begin{array}{ll}\text { a) } & 2 \\
\text { b) } & 0 \\
\text { c) } & 1 \\
\text { d) } & 1 \\
\text { e) } & 0\end{array}$ & $\begin{array}{l}\text { a) } 1 \\
\text { b) } 0 \\
\text { c) } 1\end{array}$ & $\begin{array}{ll}\text { a) } & 1 \\
\text { b) } & 0 \\
\text { c) } & 1\end{array}$ & $\begin{array}{l}\text { inglise } \\
\text { saksa } \\
\text { vene }\end{array}$ \\
\hline slovaki & $2(0,2)$ & $17-28$ & $17-24$ & $\begin{array}{ll}\text { a) } & 1 \\
\text { b) } & 1 \\
\text { c) } & 2 \\
\text { d) } & 1 \\
\text { e) } & 1 \\
\end{array}$ & $\begin{array}{l}\text { a) } 1 \\
\text { b) } 0 \\
\text { c) } 0 \\
\text { d) } 1\end{array}$ & $\begin{array}{ll}\text { a) } & 0 \\
\text { b) } & 1 \\
\text { c) } & 1\end{array}$ & $\begin{array}{l}\text { inglise } \\
\text { tšehhi } \\
\text { saksa } \\
\text { taani }\end{array}$ \\
\hline rootsi & $1(0,1)$ & 52 & 45 & $\begin{array}{ll}\text { a) } & 1 \\
\text { b) } & 1 \\
\text { c) } & 1\end{array}$ & e) 1 & b) 1 & $\begin{array}{l}\text { inglise } \\
\text { saksa }\end{array}$ \\
\hline jaapani & $1(1,0)$ & 35 & 33 & d) 1 & a) 1 & b) 1 & $\begin{array}{l}\text { inglise } \\
\text { soome }\end{array}$ \\
\hline poola & $1(0,1)$ & 24 & 23 & $\begin{array}{l}\text { b) } 1 \\
\text { c) } 1 \\
\text { d) } 1\end{array}$ & a) 1 & a) 1 & $\begin{array}{l}\text { inglise } \\
\text { vene }\end{array}$ \\
\hline portugali & $1(1,0)$ & 19 & 18 & $\begin{array}{l}\text { a) } 1 \\
\text { c) } 1\end{array}$ & a) 1 & b) 1 & $\begin{array}{l}\text { inglise } \\
\text { prantsuse } \\
\text { hispaania }\end{array}$ \\
\hline aserbaidžaani & $1(1,0)$ & 49 & 40 & $\begin{array}{l}\text { a) } 1 \\
\text { d) } 1\end{array}$ & a) 1 & b) 1 & $\begin{array}{l}\text { vene } \\
\text { türgi }\end{array}$ \\
\hline
\end{tabular}


Salvestuste märgendamine ja segmenteerimine. Aktsendikorpuse kasutamiseks eksperimentaalfoneetilistes uuringutes või ka kõnetuvastuse treenimiseks on vajalik kõik salvestused erinevatel keeletasanditel segmenteerida ja märgendada. Et kogu korpuse detailne foneetiline märgendamine IPA ${ }^{3}$ märgendust kasutades on ääretult aja- ja töömahukas, siis on korpus märgendatud ja segmenteeritud vaid osaliselt, kasutades nii käsitsi kui ka automaatset ortograafilist märgendust.

Signaalide käsitsi märgenduseks-segmenteerimiseks on kasutatud Praati (Boersma, Weenink 2011). Sõna-, silbi- ja häälikutasandil on segmenteeritud vaid see materjal, mida uurijad on vajanud vene ja soome aktsendiga kõne analüüsiks ning võrdluseks eesti L1 kõnega, s.o 10 eesti, 10 vene ja 12 soome emakeelega keelejuhi vokaalikeskset vältevastandust esindavad kahesilbilised sõnad. Käsitsi segmenteeritud materjali hulk tasapisi kasvab, eelkõige sõltuvalt sellest, millised aktsendinähtused uurijatele huvi pakuvad ja milliseid akustilisi mõõtmisi nende kirjeldamiseks on vaja teha.

Automaatne märgendus sõna- ja häälikutasandil on tehtud laboris väljatöötatud eestikeelse kõne autosegmenteerija (http://www.phon.ioc.ee/dokuwiki/doku.php?id=projects:tuvastus:est-align.et) abil. Et autosegmenteerija kasutab eesti L1 kõnematerjali põhjal treenitud häälikumudeleid, siis on L2 kõne segmenteerimise tulemus häälikutasandil väga varieeruv - mõne keelejuhi puhul on häälikupiirid määratud üsna hästi, mõne puhul aga täiesti valesti; automaatselt leitud sõnade piirid on enamiku L2 keelejuhtide puhul määratud suhteliselt täpselt. Autosegmenteerija abil on segmenteeritud loetud laused peaaegu kogu korpuses (v.a 2012 kevadel Riias tehtud salvestused).

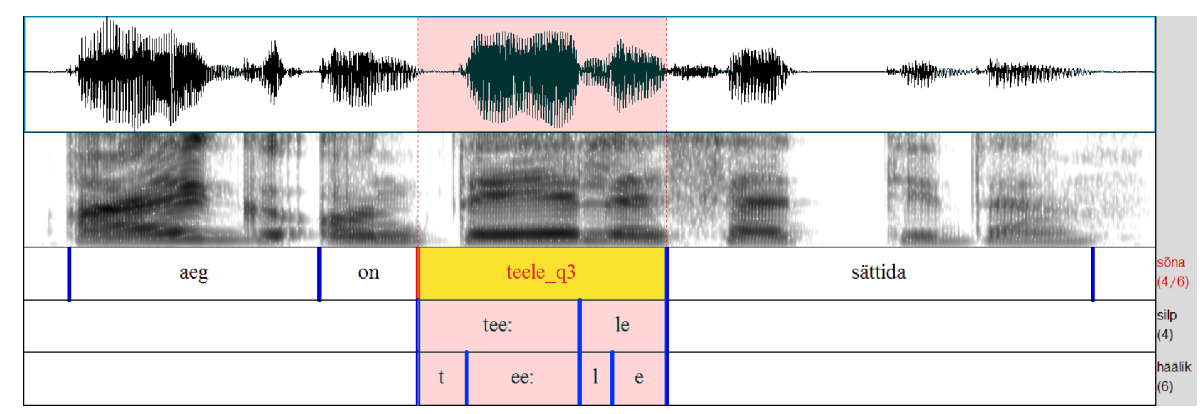

J o o n i s 1. Lause „Aeg on teele sättida” segmenteerimine sõna-, silbi- ja häälikutasandil (L2 keelejuht IR-RU).

Aktsendiuuringute tulemusi. Aktsendikorpus pakub hulgaliselt võimalusi võõrkeelse aktsendi uurimiseks, seni on jõutud seda kasutada peamiselt vene aktsendi uuringutes, esimesi tulemusi on saadud ka soome aktsendi kohta.

Vene aktsent eesti keeles väljendub kombinatsioonina erinevatest akustilistest tunnustest, millest olulisemad on temporaalse struktuuri, sõnarõhu ja häälikute kvaliteediga seotud tunnuste hälbed (Meister, L. 2005). Põhjaliku-

${ }^{3}$ International Phonetic Alphabet. 
malt on uuritud vene emakeelega keelejuhtide taju ja hääldust eesti vokaalija kestuskategooriate (lühike vs. pikk, välted) puhul (Meister, L. 2011; Meister, L., Meister, E. 2010, 2011).

\section{Eesti vokaalikategooriad vene emakeelega keelejuhtide häälduses}

Eesti keeles on üheksa vokaali /i, ü, u, e, ö, õ, o, ä, a/, vene keeles aga kuus /i, u, i, e, o, a /. Siit tulenevad huvipakkuvad uurimisprobleemid: 1) kuidas hääldavad vene emakeelega keelejuhid neid eesti vokaalikategooriaid, mis vene emakeelega keelejuhtide jaoks on uued, s.o vokaale /ü, ö, ä/; 2) kuidas mõjutab vene /íl eesti /õ/ hääldust. Aktsendikorpuse akustiline analüüs võimaldab meil neile küsimustele vastata. Selleks valime korpusest L1 ja vene emakeelega L2 keelejuhtide salvestustest sõnad, milles eesti vokaalid esinevad ühesuguses foneetilises kontekstis (kahesilbiliste sõnade esisilbis), ja mõõdame vokaalikvaliteeti iseloomustavate formantsageduste F1 ja F2 väärtused. Kuigi mees- ja naiskeelejuhtide formantsagedused on kõnetrakti erinevast suurusest tingituna erinevad, on nende võrdlemine võimalik pärast mõõteandmete normaliseerimist. Seejärel saame arvutada L1 ja L2 rühma vokaale iseloomustavad statistilised näitajad (keskväärtus, standardhälve) ja hinnata statistiliste meetoditega L1 ja L2 rühma erinevuste statistilist olulisust (p). Illustreerimaks L1 ja L2 vokaalide häälduserinevusi esitame need ühtses F2N \& F1N teljestikus (joonis 2).

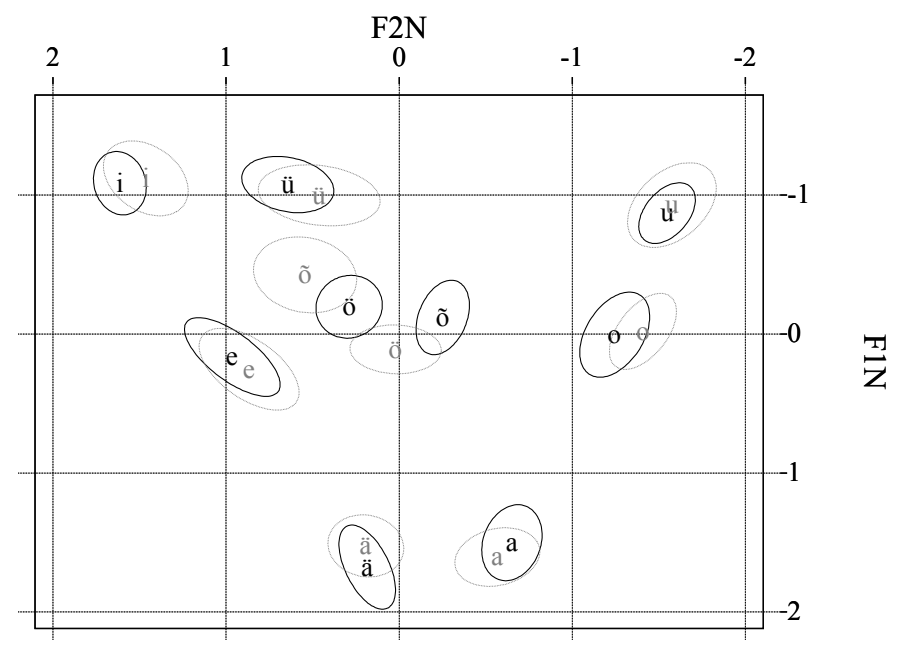

J o o n i s 2. L1 (pidevjoon) ja L2 (punktiirjoon) keelejuhtide rõhuliste vokaalide paigutus normaliseeritud F1N vs. F2N akustilises ruumis (vokaali tähis esindab normaliseeritud formantsageduste keskväärtust ja ellipsi teljed vastavaid standardhälbeid).

Jooniselt 2 näeme, et vokaalide /i/, /e/, /ä/, /u/, /o/ ja /a/ erinevused L1 ja L2 rühmas on suhteliselt väiksed, s.t vene emakeelega keelejuhid hääldavad neid lähedaselt eesti keelejuhtidega; veidi suurem erinevus (statistiliselt oluline F2N teljel $\mathrm{p}<0,05)$ L1 ja L2 häälduses on vokaali /ü/ puhul - L2 häälduses on see veidi tagapoolsem. Väga suured erinevused esinevad aga vokaalide /ö/ ja /õ/ häälduses - L2 /ö/ on L1 /ö/ suhtes oluliselt tagapoolsem ja mada- 
lam ning L2 /õ/ on L1 /õ/ suhtes oluliselt eespoolsem ja kõrgem; mõlema vokaali puhul osutusid F1N ja F2N erinevused statistiliselt eriti olulisteks ( $\mathrm{p}<0,001)$. Võrreldes L1 hääldusega, on L2 häälduses /ö/ ja /õ/ vahetanud oma kohad F2N telje suunal, s.t /õ/ on eespoolsem kui /ö/. Ilmselt mõjutab L2 keelejuhtide eesti /õ/ hääldust nende emakeelse /i/-vokaali fonoloogiline mall - vene /íl on oluliselt eespoolsem võrreldes eesti /õ/-ga (Bondarko, Verbitskaja 1987).

Saadud tulemused võivad esmapilgul olla üllatavadki ja tekitada uusi uurimist vajavaid küsimusi. Näiteks kui eesti vokaalid /ü, ö, ä/ on vene emakeelega keelejuhtide jaoks uued kategooriad, siis miks on L2 keelejuhid lähedaselt eestlastega omandanud ainult /ä/, kuid mitte /ü/ ja /ö/ häälduse, ja miks on L2 häälduses vokaalid /ö/ ja /õ/ vahetanud akustilises ruumis oma kohad.

Vastuse saamiseks käsitleme tulemusi aktsenditeooriate valguses, PAM ja SLM (vt eespool) on antud juhul selleks sobivaimad.

Mõlemad mudelid prognoosivad, et kui foneetiline kaugus L1 kategooriate ja neile vastenduvate L2 kategooriate vahel on väike, siis assimileeruvad L2 kategooriad vastavate L1 kategooriatega. See hüpotees näib paika pidavat vokaalide /i/, /e/, /u/ ja /o/ puhul; eesti (Liiv, Remmel 1970) ja vene (Fant 1970) isoleeritult hääldatud vokaalide mõoteandmed näitavad, et need vokaalid on kahes keeles akustiliselt lähedased.

Nimetatud mudelite teine hüpotees väidab, et L1 ja L2 kategooriate assimilatsioon toimub allofoonilisel, mitte abstraktsete foneemide tasandil. Et vene vokaal /a/ realiseerub kontekstist sõltuvalt [æ] allofoonina, näiteks $c я \partial b$ [s'æt'] 'istu', või [a] allofoonina, näiteks палка [pałkı] 'kepp' (Bondarko jt 2000: 26-28), siis ei ole eesti vokaalide /a/ ja /ä/ kvaliteedi kontrast vene emakeelega kuulajale võõras ning need assimileeruvad vene /a/-vokaali allofoonidega [a] ja [æ]. Seetõttu ei valmista eesti /ä/ hääldus vene emakeelega kuulajatele erilisi probleeme.

Kolmanda hüpoteesi kohaselt luuakse L1-st akustiliselt ja pertseptiivselt erineva L2 häälikuklassi jaoks uus kategooria. See peaks aset leidma vene emakeelega keelejuhtidel eesti vokaalide /ü/ ja /ö/ ning ka /õ/ puhul. Joonise 2 põhjal võib arvata, et /ü/ puhul ongi uus kategooria osaliselt välja kujunenud - L2 /ü/ hääldus hälbib L1 hääldusest suhteliselt vähe, kuid /ö/ ja /õ/ puhul on olukord keerulisem. Vene vokaali /i/ foneetilise läheduse tõttu on tingimused uute kategooriate tekkimiseks L2 tajuruumis ebasoodsad, seetõttu on vene emakeelega keelejuhil neid raske kuuldeliselt eristada ja häälduses sarnaselt eestlastega realiseerida. L2 /õ/ häälduses jääbki domineerima nende emakeelne /ì/-vokaali mall, s.t eesti /õ/ assimileerub vene /ì/-vokaaliga ja eesti /ö/ jaoks on tekkinud uus kategooria, mis häälduses realiseerub /õ/-vokaalist tagapoolsemana, s.t L2 akustilises ruumis on eesti /ö/ ja /õ/ vahetanud oma kohad.

\section{Eesti väldete hääldus: eesti, vene ja soome emakeelega keelejuhtide võrdlus}

Eesti ja soome keel on kvantiteedikeeled, s.t kestusel on neis keeltes fonoloogiline funktsioon. Eesti keeles esinevad vokaalid segmenditasandil lühikese või pika monoftongina ja diftongina, konsonandid lühikesena või geminaadina ja konsonantühendina; takti (värsijala) tasandil on võimalik kolme välte eristus. Traditsiooniliselt kasutatakse väldete tähistamiseks ingliskeelse ter- 
mini quantity lühendit, vastavalt Q1 kui esimene, Q2 teine ja Q3 kolmas välde. Üldtunnustatud on seisukoht, et vältevastandus põhineb rõhulise ja rõhuta silbi erinevatel kestussuhetel (Lehiste 1960), olulist rolli väldete eristamisel mängivad ka põhitooni harja asukoht ja akustilise energia jaotus taktis (Lehiste 1997; Eek 1994; Lippus jt 2009). Varasematest uurimustest leitud tüüpilised välteid iseloomustavad kestussuhted on järgmised: Q1 taktis 0,6 0,9, Q2 taktis 1,4 - 2,0 ja Q3 taktis 2,0 - 3,9 (Meister, L. 2011: tabel 4).

Soome keele kvantiteedisüsteem on lihtsam - kvantiteedivastandus on binaarne ja leiab aset ainult segmentaalsel tasandil. Erinevalt eesti keelest võib vokaalide kestusvastandus aset leida nii rõhulistes kui rõhututes silpides, ka konsonantide kestusvastandus võib aset leida sõltumatult rõhust, kuid see pole võimalik sõna alguses ja lõpus ega konsonantühendites.

Vene keeles ei ole kestusel fonoloogilist rolli ja seetõttu ei esine ka kestusel põhinevat vastandust. Erinevalt eesti keelest on kestus vene keeles sõnarõhu peamine tunnus - rõhulises silbis on vokaalide kestus (1,5 kuni 2 korda) suurem võrreldes vokaalidega rõhutus silbis, kus lisaks vokaali lühemale kestusele kaasneb ka selle kvalitatiivne redutseerumine (Bondarko 1998).

Lähtuvalt kestuse erinevast rollist eelnimetatud keeltes võib eesti väldete realiseerimisel L2 kõnes oodata erinevaid kestushälbeid. Soome emakeelega keelejuhtidel (tähistatud kui L2-FI) peaks olema eelis vene emakeelega keelejuhtide (tähistatud kui L2-RU) ees - eesti väldete hääldamisel saavad nad toetuda soome keele kestusvastandustele, samas võivad vene emakeelega keelejuhtidel abiks olla rõhulise ja rõhuta silbiga kaasnevad kestusvariatsioonid.

Väldete häälduse võrdlemiseks kolmes rühmas (L1-EE ja L2-RU rühmas 10 keelejuhti; L2-FI rühmas 12 keelejuhti, kõigis rühmades on mehi ja naisi võrdselt) on valitud vokaalikeskse vältevastandusega kahesilbilised sõnad (9 sõna iga vältestruktuuri kohta, 27 sõna iga keelejuhi kohta). Neist on mõõdetud rõhulise ja rõhuta silbi vokaalide kestused ja arvutatud välteid iseloomustavad kestussuhted, tulemused on esitatud tabelis 2 ja karpdiagrammidena joonisel 3 .

Tulemuste statistiline analüüs näitas, et $\mathbf{Q 1}$ sõnades on L1-EE ja L2-FI rühmade tulemused lähedased - V1 ja V2 kestused ja V1/V2 suhe pole kahes rühmas statistiliselt olulised $(\mathrm{p}<1)$. L1-EE ja L2-RU rühmade võrdlus aga näitas olulisi erinevusi kõigis näitajates: V1 ( $p<0,005)$, V2 (p < 0,05) ja V1/V2 ( $p<0,001)$. Q2 sõnades esinesid olulised erinevused L1-EE ja L2-FI rühmade vahel $(\mathrm{p}<0,001)$, kuid mitte L1-EE ja L2-RU rühmade puhul $(\mathrm{p}<1)$. Q3 sõnades on aga Q2-le vastupidine tulemus: L1-EE ja L2-FI rühmade erinevused on ebaolulised ( $p<1)$ ning L1-EE ja L2-RU erinevused on vägagi olulised $(\mathrm{p}<0,001)$.

Näeme, et mõlema L2 rühma loetud lausetes eesti Q2 ja Q3 sõnad ei eristunud, kuid kahe rühma hääldusele olid iseloomulikud erinevad prosoodilised mustrid. Miks hääldavad soome emakeelega keelejuhid Q2 ja Q3 sõnu sarnaselt eesti keelejuhtidele omase Q3 kestusmalliga, aga vene emakeelega kõnelejad sarnaselt eesti kõnelejate Q2 malliga? Vastuseid võiks otsida desensibiliseerimise ja tunnuse hüpoteesidele (vt eespool) toetudes. Esimese kohaselt on kestus kuuldeliselt hästi tajutav akustiline tunnus, sõltumata sellest, kas kõneleja emakeel kasutab kestust kontrastiivselt või mitte; teine hüpotees aga väidab, et L2 kestuskategooriate taju sõltub kestuse rollist emakeeles, ja kui 
Tabel 2.

\section{V1 ja V2 vokaalide keskmised kestused ja V1/V2 keskmised kestussuhted ning vastavad standardhälbed $(\sigma)$ Q1, Q2 ja Q3 sõnades L1-EE, L2-FI ja L2-RU keelerühmades}

\begin{tabular}{cccccccc}
\hline & \multirow{2}{*}{ Keelerühm } & \multicolumn{2}{c}{ Q1 } & \multicolumn{2}{c}{ Q2 } & \multicolumn{2}{c}{ Q3 } \\
\cline { 3 - 8 } & Leskm & $\sigma$ & Keskm & $\sigma$ & Keskm & $\sigma$ \\
\hline \multirow{2}{*}{$\begin{array}{c}\text { V1 kestus, } \\
\text { ms }\end{array}$} & L2-EI & 82 & 15,6 & 144 & 29,0 & 174 & 26,7 \\
& L2-RU & 93 & 22,0 & 170 & 48,2 & 173 & 44,8 \\
& L1-EE & 112 & 28,3 & 85 & 25,0 & 61 & 12,2 \\
V2 kestus, & L2-FI & 114 & 35,8 & 66 & 25,7 & 66 & 27,6 \\
ms & L2-RU & 98 & 41,1 & 91 & 36,3 & 88 & 31,4 \\
\hline \multirow{2}{*}{ V1/V2 } & L1-EE & 0,8 & 0,21 & 1,8 & 0,42 & 2,9 & 0,63 \\
suhe & L2-FI & 0,7 & 0,22 & 2,8 & 1,03 & 2,8 & 0,92 \\
& L2-RU & 1,1 & 0,52 & 1,8 & 0,52 & 1,8 & 0,63 \\
\hline \hline
\end{tabular}

see ei kasuta kestust kontrastiivselt, siis võib eeldada raskusi L2 kestuskategooriate omandamisel.

L2-FI keelejuhtide Q1 sõnade mõõtmisandmed toetavad tunnuse hüpoteesi. Soome emakeelega kõnelejad said Q1 hääldusega paremini hakkama kui vene emakeelega kõnelejad: soome emakeelega kõnelejate Q1 hääldusmuster oli väga lähedane L1 keelejuhtide Q1 hääldusele tõenäoliselt tänu kestuse kontrastiivsele rollile soome keeles. Kuigi L2-RU kõnelejate Q1 sõnade kestused ja kestussuhted erinesid L1 hääldusest, said nad edukalt hakkama Q1 vs. Q2 vastanduste realiseerimisega, vaatamata kestuse mittekontrastiivsele rollile nende emakeeles. See fakt annab omakorda tuge desensibiliseerimise hüpoteesile. Mõlemad hüpoteesid jäävad aga hätta L2 keelejuhtide Q2 vs. Q3 hääldustulemuste selgitamisega. On ootuspärane, et L2-RU rühma jaoks on Q2 ja Q3 kestusmustrite eristamine kõnes raske ülesanne, sest nende emakeeles ei esine analoogiat, millele toetuda. Üllatavad on aga L2-FI rühma tulemused: tunnuse hüpoteesi kohaselt peaks kestuse kontrastiivne roll soome keeles hõlbustama kestusvastandustel põhinevate kategooriate eristamist nii tajus kui kõnes, kuid ilmselt on eesti Q2 ja Q3 taktiisokrooniale püüdlevad kestusmustrid liialt keerukad lihtsama (segmenditasemel binaarset kestusvastandust sisaldava) prosoodilise süsteemiga kvantiteedikeele kõneleja jaoks. Näib, et siin on veel ruumi uute teoreetiliste mudelite arendamiseks, mis suudaks selgitada aktsendinähtusi ka keerukamate, mitme tunnuse kombinatsioonil põhinevate fonoloogiliste kategooriate puhul. 

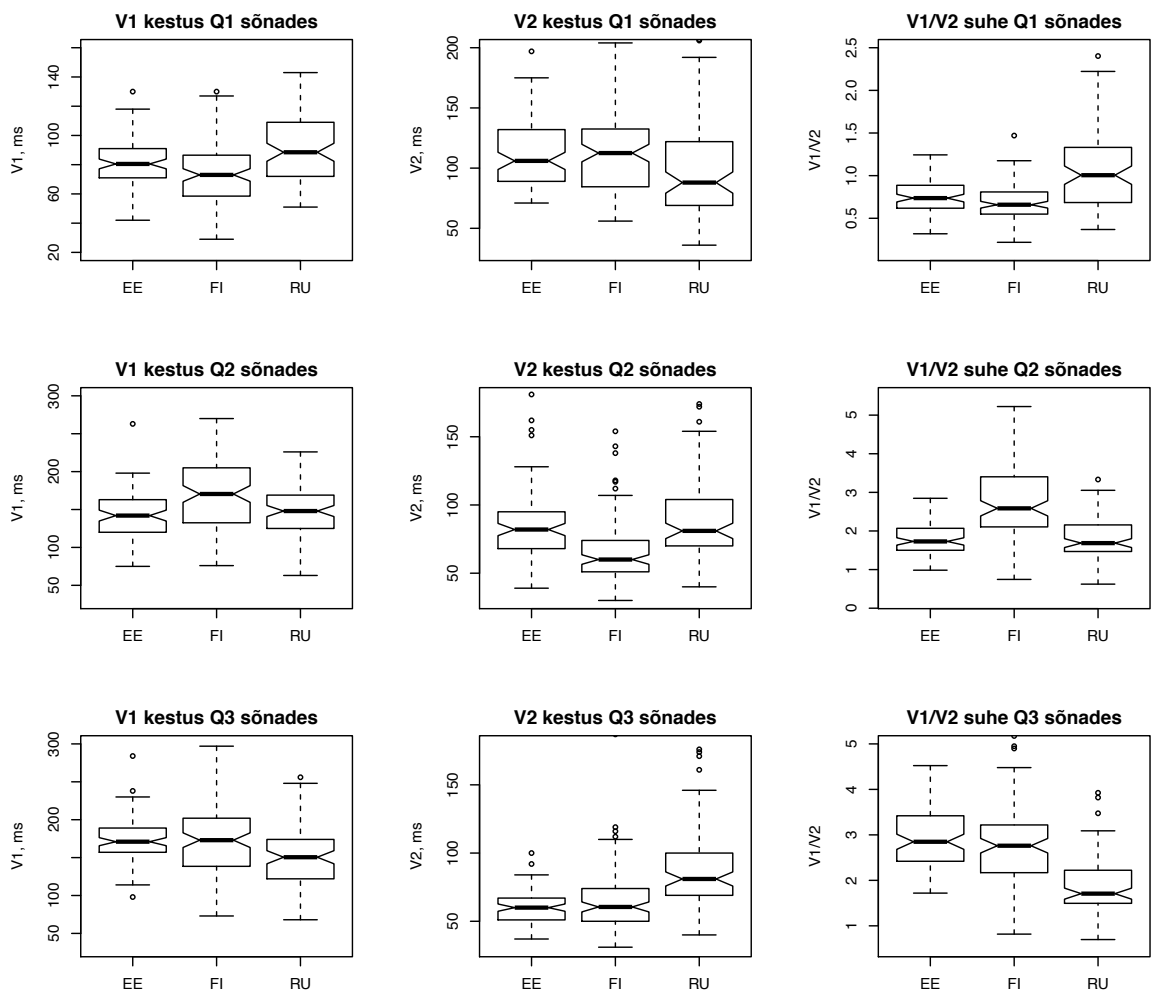

J o o n i s 3. V1 (vasak veerg) ja V2 (keskmine veerg) vokaalide kestused ja V1/V2 kestussuhe (parem veerg) Q1 (ülemine rida), Q2 (keskmine rida) ja Q3 (alumine rida) sõnades L1, L2-FI ja L2-RU keelerühmades.

\section{Kokkuvõte}

Aktsendikorpuse arendamine jätkub nii uute keelejuhtide salvestamise kui ka olemasoleva materjali segmenteerimise-märgendamisega, eriti oodatud on korpuses vähem esindatud ja seni esindamata keeletaustaga keelejuhid. Artiklis toodud aktsendiuuringute näited on vaid väike osa uurimisprobleemidest, mis eri keelepaaride puhul uurimist vääriks ja uudseid tulemusi võiks pakkuda. Esitatud uurimistulemused peaksid pakkuma mõtlemisainet ka eesti keele kui võõrkeele õpetajatele-metoodikutele, kuidas eri emakeelega õpilastele paremini õpetada erinevate eesti keele fonoloogiliste kategooriate eristamist nii tajus kui ka häälduses. Loomulikult ei paku esitatud tulemused veel konkreetseid lahendusi ühe või teise hääldusvea parandamiseks, sobiva metoodika väljatöötamiseni on ilmselt käia veel pikk tee.

\section{Kirjandus}

B e st, Catherine T. 1994. Learning to perceive the sound pattern of English. Advances in Infancy Research, kd 9. Toim C. Rovee-Collier, L. Lipsitt. Norwood: Ablex, lk 217-304. 
B e st, Catherine T., Tyler, Michael D. 2007. Nonnative and second language speech perception: Commonalities and complementarities. - Second Language Speech Learning: The Role of Language Experience in Speech Perception and Production. Toim M. J. Munro, O.-S. Bohn. Amsterdam: John Benjamins, lk 13-34.

Birdsong, David, Molis, Michelle 2001. On the evidence for maturational constraints in second language acquisition. - Journal of Memory and Language, kd 44, lk 235-249.

B ir d s ong, David 2006. Age and second language acquisition and processing: A selective overview. - Language Learning, kd 56, lk 9-49.

B i r d s o n g, David 2007. Nativelike pronunciation among late learners of French as a second language. - Language Experience in Second Language Speech Learning. Toim O.-S. Bohn, M. Munro. Amsterdam: John Benjamins, lk 99-116.

B o e r s m a, Paul, Weenink, David 2011. Praat: doing phonetics by computer (Version 5.2.09) [arvutiprogramm]. http://www.praat.org/ (9. I 2011).

B o h n, Ocke-Schwen 1995. Cross-language speech perception in adults: First language transfer doesn't tell it all. - Speech Perception and Linguistic Experience. Issues in Cross-Language Research. Toim W. Strange. Baltimore: York Press, lk 279-304.

В o n d a r k o 1977 = Бондарко, Аия Васильевна 1977. Звуковой строй современного русского языка. Москва: Просвещение.

В o n d a r k o 1998 = Бондарко, Пия Васидьевна 1998. Фонетика современного русского языка. Санкт-Петербург: Санкт-Петербургский государственный университет.

B o ndarko jt 2000 = Бондарко, Лия Васильевна, Вербицкая, Дюдмила Алексеевна, Гордина, Мирра Вениаминовна 2000. Основы общей фонетики. Санкт-Петербург: Филологический факультет Санкт-Петербургского государственного университета.

B o nd a rko, Ve rbitsk a a 1987 = Бондарко, Дия Васидьевна, Вербицкая, Пюдмила Алексеевна 1987. Интерференция звуковых систем. Денинград: Издательство Ленинградского Университета.

B o ng a e rts, Theo, Planken, Brigitte, S chils, Erik 1995. Can late starters attain a native accent in a foreign language? A test of the critical period hypothesis. - The Age Factor in Second Language Acquisition. Toim D. Singleton, Z. Lengyel. Clevedon, GB: Multilingual Matters Limited, lk 30-50.

Che our, Marie, Ceponiene, Rita, Lehtok oski, Anne, Lu uk, Aavo, Allik, Jüri, Alho, Kimmo, N äätäne n, Risto 1998. Development of language-specific phoneme representations in the infant brain. - Nature Neuroscience, kd 1, lk 351-353.

Cucchiarini, Catia, Driesen, Joris, Van hamme, Hugo, S a nders, Eric 2008. Recording Speech of Children, Non-Natives and Elderly People for HLT Applications: the JASMIN-CGN Corpus. LREC 2008, Marrakech, Marocco, lk 1445-1450.

Cylwik, Natalia, Wagner, Agnieszka, Dem enko, Grazyna 2009. The EURONOUNCE corpus of non-native Polish for ASR-based Pronunciation Tutoring System, SLaTE 2009. ISCA International Workshop on Speech and Language Technology in Education, Wroxall Abbey Estate, Warwickshire, England, 3rd-5th September 2009.

D u p o u x, Emmanuel, P e p e r k a m p, Sharon 2002. Fossil markers of language 
development: phonological 'deafnesses' in adult speech processing. - Phonetics, Phonology, and Cognition. Toim B. Laks, J. Durand. Oxford: Oxford University Press, lk 168-190.

E e k, Arvo 1987. The perception of word stress: A comparison of Estonian and Russian. - In Honor of Ilse Lehiste. Ilse Lehiste Pühendusteos. Toim R. Channon, L. Shockey. Dordrecht, Holland-Providence, USA: Foris Publications, lk 19-32.

E e k, Arvo 1994. Studies on quantity and stress in Estonian. (Dissertationes Philologiae Estonicae Universitatis Tartuensis 4.) Tartu: Tartu Ülikooli Kirjastus.

E ek, Arvo, Meister, Einar 1999. Estonian speech in the BABEL multi-language database: Phonetic-phonological problems revealed in the text corpus. Proceedings of LP'98: Item Order in Language and Speech. Toim O. Fujimura, B. Joseph, B. Palek. Prague: The Karolinum Press, lk 529-546.

Eimas, Peter D., Miller, Joanne L., Jusczyk, Peter W. 1987. On infant speech perception and the acquisition of language. - Categorical Perception: The Groundwork of Cognition. Toim S. Harnard. Cambridge, MA: Cambridge University Press, lk 161-195.

F a n t, Gunnar 1970. Acoustic Theory and Speech Production with Calculations Based on X-Ray Studies of Russian Articulations. (Description and Analysis of Contemporary Standard Russian.) The Hague: Mouton.

Fle ge, James E. 1991. The interlingual identification of Spanish and English vowels: Orthographic evidence. - Quarterly Journal of Experimental Psychology, kd 43A, lk 701-731.

F l e g e, James E. 1995. Second language speech learning: Theory, findings, and problems. - Speech Perception and Linguistic Experience: Issues in Gross-Language Research. Toim W. Strange. Timonium: York Press, lk 233-275.

G i c k, Bryan, W i l s o n, Ian, K o c h, Karsten, C o o k, Clare 2004. Language-specific articulatory settings: Evidence from inter-utterance rest position. - Phonetica, kd 61, lk 220-233.

H a ye s, Bruce 1995. Metrical Stress Theory: Principles and Case Studies. Chicago-London: The University of Chicago Press.

J e n n e r, Bryan 2001. 'Articulatory setting': Genealogies of an idea. - Historiographia Linguistica, kd 28, lk 121-141.

J o h n s o n, Jacqueline S., N e w p ort, Elissa L. 1989. Critical period effects in second language learning: The influence of maturational state on the acquisition of English as a second language. - Cognitive Psychology, kd 21, lk 60-99.

Kolosov 1971 = Колосов К. М. 1971. К вопросу об артикуляционной базе языка. - Теоретические проблемы фонетики и обучение произношению. Москва: МГУ, lk 36-60.

Ku h 1, Patricia K. 1991. Human adults and human infants show a „perceptual magnet effect” for the prototypes of speech categories, monkeys do not. - Perception \& Psychophysics, kd 50, lk 93-107.

Ku h l, Patricia K., Willi a m s, Karen A., La c e rd a, Francisco, S teven s, Kenneth N., Lind blom, Björn 1992. Linguistic experience alters phonetic perception in infants by six months of age. - Science, kd 255, lk 606-608.

K u l e š o v, M i š i n 1987 = Кулешов, Владимир Васильевич, Мишин, Александр Борисович 1987. Сопоставление артикуляционных баз ангдийского и русского языков и фонетическая интерференция. Москва: МГУ.

Kuznetsova 1975 = Кузнецова, А. М. 1975. Вопросы интерференции и типологии фонетических явлений. - Теоретическая фонетика и обучение произношению. Москва: УДН, lk 152-158. 
L a d o, Robert 1957. Linguistics across Cultures: Applied Linguistics for Language Teachers. Ann Arbor: University of Michigan Press.

L a $\mathrm{m}$ e l, Lori F., S c h i e l, Florian, F o u r c i n, Adrian, M a r i a n i, Joseph, T i 11 m a n n, Hans G. 1994. The translanguage English database (TED). ICSLP 1994, lk 1795-1798.

L a n d e r, Terri 2007. CSLU: Foreign Accented English Release 1.2, Linguistic Data Consortium, Philadelphia.

Le his te, Ilse 1960. Segmental and syllabic quantity in Estonian. - American Studies in Uralic Linguistics. (Uralic and Altaic Series 1.) Bloomington: Indiana University Press, lk 21-82.

L e h i s t e, Ilse 1970. Suprasegmentals. Cambridge, Massachusetts-London, England: The MIT Press.

L e h is te, Ilse 1997. Search for phonetic correlates in Estonian prosody. - Estonian Prosody: Papers from a Symposium. Toim I. Lehiste, J. Ross. Tallinn: Institute of Estonian Language, lk 11-35.

L e n n e b e r g, Eric H. 1967. Biological Foundations of Language. New York: John Wiley.

Li i v, Georg, R e m m el, Mart 1970. On acoustic distinctions in Estonian vowel system. - Советское финно-угроведение, kd 6, lk 7-23.

Li p p u s, Pärtel, P aj u s a l u, Karl, Allik, Jüri 2009. The tonal component of Estonian quantity in native and non-native perception. - Journal of Phonetics, kd 37, lk 388-396.

Ljubimova 1985 = Любимова Нина Александровна 1985. Фонетическая интерференция. Ленинград: ЛГУ.

L o n g, Michael H. 1990. Maturational constraints on language development. Studies in Second Language Acquisition, kd 12, lk 251-285.

M a j o r, Roy C. 2001. Foreign Accent: The Ontogeny and Phylogeny of Second Language Phonology. Mahwah-London: Lawrence Erlbaum Associates Publishers.

M c Alli st e r, Robert, F le g e, James E., P i s k e, Thorsten 2002. The influence of L1 on the acquisition of Swedish quantity by native speakers of Spanish, English and Estonian. - Journal of Phonetics, kd 30, lk 229-258.

M e i s t e r, Lya 2005. Vene aktsent eesti keeles. Akustiline analüüs. Magistritöö. Tallinn: Tallinna Pedagoogikaülikool.

M e i s t e r, Lya 2011. Eesti vokaali- ja kestuskategooriad vene emakeelega keelejuhtide tajus ja häälduses. Eksperimentaalfoneetiline uurimus. (Dissertationes philologiae Estonicae Universitatis Tartuensis 30.) Tartu: Tartu Ülikooli Kirjastus.

M e is t e r, Lya, M e is t e r, Einar 2010. Perception of Estonian vowel categories by native and non-native speakers. - Proceedings of INTERSPEECH 2010 Spoken Language Processing for All: 26-30 September 2010. Makuhari, Chiba, Japan: International Speech Communication Association, lk 1870-1873.

M e is t e r, Lya, M e i s te r, Einar 2011. Perception of the short vs. long phonological category in Estonian by native and non-native listeners. - Journal of Phonetics, kd 39, lk 212-224.

Mennen, Ineke, De Le e uw, Ester, S c obbie, James M., S chaeffler, Felix, Sch a effler, Sonja 2010. Measuring language-specific phonetic settings. - Second Language Research, kd 26, lk 13-41.

M il d e, Jan-Totsten, G u t, Ulrike 2002. A prosodic corpus of non-native speech. - Proceedings of the Speech Prosody 2002 conference, 11-13 April 2002. Toim B. Bel, I. Marlien. Aix-en-Provence: Laboratoire Parole et Langage, lk 503-506. 
M u n r o, Murray 2006. Perspectives on foreign-accented speech: Issues, methods, and findings. [Ettekanne seminaril Workshop on Variation in Speech Production and Perception, August 4-6, 2006, Trondheim.]

Poliva n o v, Evgeni D. 1931. La perception des sons d'une langue étrangère. Travaux du Cercle Linguistique de Prague, kd 4, lk 79-96.

P o l k a, Linda, W e r k e r, Janet F. 1994. Developmental changes in perception of nonnative vowel contrasts. - Journal of Experimental Psychology: Human Perception and Performance, kd 20, lk 421-435.

R a a b, Martin, Gr u h n, Rainer, N o e t h, Elmar 2007. Non-Native Speech Databases. - IEEE Workshop on Automatic Speech Recognition \& Understanding, ASRU 2007, December 9-13. Toim Sadaoki Furui, Tatsuya Kawahara. Kyoto, Japan, lk 413-418.

S e l i n k e r, Larry 1972. Interlanguage. - International Review of Applied Linguistics, kd 10, lk 209-231.

Schiel, Florian, Draxler, Christoph 2003. Production and Validation of Speech Corpora. Bavarian Archive for Speech Signals. München: Bastard Verlag.

Ž g a n k, Andrej, Ve r d o n i k, Darinka, M a r k u š, Aleksandra Zögling, K a č i č, Zdravko 2006. SINOD - Slovenian non-native speech database. LREC 2006, Genoa, Italy, lk 1620-1623.

T a k a g i, Naoyuki 1993. Perception of American English /r/ and // by adult Japanese learners of English: a unified view. Ph.D. Dissertation. University of California, Irvine.

Trubetzk oy, Nikolai S. 1939. Grundzüge der Phonologie. (Travaux du Cercle Linguistique de Prague 7.)

Van Engen, Kristin J., B a e s e-B e rk, Melissa, B a ke r, Rachel E., C h o i, Arim, Ki m, Midam, B r a d l o w, Ann R. 2010. The Wildcat Corpus of Nativeand Foreign-Accented English: Communicative efficiency across conversational dyads with varying language alignment profiles. - Language and Speech, kd 53, lk 510-540.

We r ker, Janet F., Te es, Richard C. 1984. Cross-language speech perception: Evidence for perceptual reorganization during the first year of life. - Infant Behavior and Development, kd 7, lk 49-63.

Wils o n, Ian, Gi c k, Bryan 2006a. Articulatory settings of French and English monolinguals and bilinguals. - Journal of the Acoustical Society of America, kd 120, lk 3295-3296.

Wil s o n, Ian, Gi ck, Bryan 2006b. Ultrasound technology and second language acquisition research. - Proceedings of the 8th Generative Approaches to Second Language Acquisition Conference (GASLA 2006). Toim M. G. O’Brien, C. Shea, J. Archibald. Somerville, MA: Cascadilla Proceedings Project, lk 148-152.

Ya m a d a, Reiko A. 1995. Age and acquisition of second language speech sounds perception of American English / $/ /$ and // by native speakers of Japanese. Speech Perception and Linguistic Experience: Issues in Cross-Language Research. Toim W. Strange. Timonium: York Press, lk 305-320.

Young - S c hol te n, Martha 2002. Orthographic input in L2 phonological development. - Papers in Honour of Henning Wode. An Integrated View of Language Development. Toim P. Burmeister, T. Piske, A. Rohde. Trier: Wissenschaftlicher Verlag Trier, lk 263-279. 


\section{Foreign Accent Corpus and Studies of Non-Native Speech}

Keywords: native language, second language, speech corpus, non-native pronunciation, vowel categories, duration oppositions

The article begins with an overview of the nature and theoretical models of foreign accent, then the Foreign Accent Corpus developed at the Laboratory of Phonetics and Speech Technology, Institute of Cybernetics at Tallinn University of Technology, is introduced, and finally some research results are discussed. As a rule, adult language learners are faced with difficulties in the pronunciation of foreign sounds and these difficulties result in a foreign accent. In order to study different aspects of foreign accent our accent corpus was initiated in 2006. The aim of the Estonian Foreign Accent Corpus (EFAC) is to provide systematic and high-quality non-native speech data for experimental phonetic studies and for language technology developments.

The text corpus involves 130 neutral sentences including the main phonological oppositions of Estonian, eight questions, two passages, and prompts to elicit spontaneous speech (self-introduction, description of three pictures).

Most of the speech recordings have been done in our own recording studio; several subjects have been recorded at their home universities in Finland (Oulu, Helsinki and Turku), France (Paris), Austria (Wien) and Latvia (Riga). All subjects have filled a questionnaire containing questions about their age, native language, age of learning Estonian, where and how they have learnt the language and how often they use it, as well as self-assessment of their knowledge of Estonian. By now we have recorded 162 non-native speakers (L2) of Estonian representing 18 different language backgrounds. In addition, a reference group of 20 native Estonian speakers (L1) has been recorded.

The EFAC constitutes a valuable resource for phonetic studies of L2 speech. So far, we have been focused on the perception and production of Estonian vowels, short/long oppositions and quantity degrees by native speakers of Russian and Finnish as compared to L1 subjects. The results reveal differences in L1 and L2 groups due to differences in the vowel systems and the different role of duration in Finnish, Russian and Estonian.

Lya Meister (b. 1957), PhD, Institute of Cybernetics at Tallinn University of Technology, researcher, lya@phon.ioc.ee

Einar Meister (b. 1957), PhD, Institute of Cybernetics at Tallinn University of Technology, senior researcher, einar@ioc.ee 